\title{
Towards the Uniform Civil Code and Personal Laws in India: Gender Equality Perspective
}

\author{
Alim A* \\ Department of Law, University of Rajshahi, Bangladesh
}

*Corresponding author: Abdul Alim, Professor Department of Law, University of Rajshahi, 6205, Bangladesh, Tel: 88-01714896132; Email: alimlaw05@gmail.com

\section{Perspective}

Volume 4 Issue 4

Received Date: October 20, 2021

Published Date: November 01, 2021

DOI: $10.23880 /$ abca-16000206

\section{Abstract}

Family life and personal law in India express together a complex blend of historical, philosophical and political aspects. Family law is setting out a framework for thinking about how personal life affects the most profound aspects of our lives and communities. But the political issues are facing problematic as politician are not in favor of this because fear of losing their vote bank. There is not only political issue but also legal issue. Again, in the matters of personal law segment pertaining to marriage, dowry, divorce, adoption, legitimacy, wills, and inheritance each individual of different backgrounds must appeal to their respective religious laws for guidance or rulings. In a modern secular India, balancing the claims of religious communities in secular nature has caused some difficult problems as a nation. The author will scrutinize how personal laws in secular India provides an inclusive look into the issues and challenges and what extent State can interfere in the matters of religion so as to remove the hindrance in the governance. This article will also analyze the basis of national integration by removing disparate reliability on law which has conflicting ideologies of gender equality.

\section{Origin of Personal Laws in India}

Hindus were formerly called Gentus or Gentoos [1] by the occidentals [2]. The word "Gentoo" found in Vivadarnavasetu [3]. Furthermore, it appears more probable that the name has been derived from that of the river Sindhu which is also called Indus. The territory adjacent to the river Sindhu is the place where the Hindu aryans first settled, and that area was called Sindhusthan [4]. Hindu law is an ancient law in the world. In Indian subcontinent, Hinduism is known as Sanatana Dharma (everlasting religion) [5]. Perhaps, 4000 $\mathrm{BC}$ the religious book of Hindus named Veda was drawn [6]. According to the Hindu saints, holy men, legislators, and rulers gods and goddesses established ideologies, principles, rules and regulations are considered as the base of Hindu Law. The Code of Manu was based on customs and practices of the society then extant [7]. The Code includes provisions of strict conjugal fidelity and prohibited polyandry. Wife's were entailed to enjoy limited liberty. All men were obliged to respect women. According to Manu, "where females are dishonored, there the deities are please; but where they are dishonored, there all religious acts become fruitless" [8]. It is the duty of a husband who performs of marriage with Vedic verses always makes his woman happy [9]. Manu also says, "Women must always be honored and respected by the father, brother, husband and brothers-in-law who desire their own welfare. If the female members live in grief, the family is destroyed. If the female members are happy, the family flourishes in all direction [10]. A uniform civil code will mean a set of common personal laws for all citizens. Personal law covers property, marriage and divorce, inheritance and succession.

\section{Diversified Indian Society}

India is like a black hole where Hinduism, Jainism, Buddhism, Islam, Sikhism and Christianity are the major religions. There is diversity not only in regard to racial 
compositions, religious and linguistic distinction but also in patterns ofliving, life styles, land tenure systems, occupational pursuits, inheritance and succession law, and practices and rites related to birth, marriage death etc. After Independence in 1947, Indian guardians prescribed the aim of its growth into a modern secular democracy. As mentioned in Article 44 of the Constitution of India, it suggests that there should be Uniform Civil Code above all the personal laws. Constitution provides "the State shall endeavor to secure for the citizens a uniform civil code throughout the territory of India". The modern law tells us to remind individuals more openly of their social responsibilities. In India, Article $51 \mathrm{~A}$ of the Constitution has been phrased in terms of the fundamental duties and enshrined in an important case Vijaya Manohar Arhat [11], where it was held that a Hindu daughter, also after marriage, has a duty to maintain her aged parents.

In India, there is a Hindu Marriage Act, a Muslim Personal Law (Shariat) Application Act, 1937, a Christian Marriage Act and a Parsee Marriage and Divorce Act. Hindu Marriage Act applies to any person who is a Hindu, Buddhist, Jain or Sikh by religion. There is also a Special Marriages Act, 1954 under which people can perform marriage irrespective of the religion followed by either person. These laws deal with the matters involving marriage, divorce, inheritance, adoption, and maintenance of the respective religions. Now if humanity has common interest enjoying their life mean that all these laws will be replaced by a new law which will be applicable for all irrespective of their religions.

The British applied a common criminal code for all but allowed the religious laws to be applied in the case of personal matters. The latter laws were to be applied by the local courts when dealing with personal disputes between people of the same religion. Even amongst the Hindus, different rules were used in different regions and for different castes. The Shariat law of 1937 was passed to govern the personal matters of all Indian Muslims would be governed by Islamic laws.

\section{Towards the Uniform Family Code}

Communalism is so strong in India because different communities do not have the same status in law [12]. As Dhagamwar consistently argues in many contexts by respecting diversity and on uniformity but is the first instance, by its own uncoordinated and un-reflected program of secularization and uniformities. In the present time it perceived as threatening by almost all communities, even the Hindu majority. From the decades experience the Hindu and Muslim never really agreed to the secularizing reforms of their personal laws [13]. Now the great euphoria following the Shah Bano case of 1985 was rapidly smothered by the much misunderstood Muslim Women (Protection of Rights on Divorce) Act 1986 that appears to treat Muslim divorced wives differently from others. Everyone must be very aware of the major difficulties of enforcing legal uniformity in a country like India and Dhagamwar remarkably open-ended conclusion which is Voluntary or compulsory, it seems that if and when the Uniform Civil Code is introduced, there is a strong possibility of a period of deep social unrest taking place. Unless the government is prepared to ride out this period, if it then gives in to those who don't want the Uniform Civil Code, more damage will be done by introducing than by withholding the Uniform Civil Code [14].

What is clearly needed now is a major re-assessment of some very fundamental issues in the debate on legal uniformity in India: To what extent does modern India need legal uniformity at all?. Further, personal law system is really as suppressive and divisive, perpetuating differential statues create only barriers and injustice. Tahir Mahmood described a few amendments made on minorities laws mainly India and during the Pakistan period and also after the creation of Bangladesh [15]. Bangladesh government has not passed any law that may influence the personal laws of Buddhists, Christians and Hindus. However, two Acts concerning cruelty to women [16] and practice of dowry were passed later although these two Acts are meant for all communities and cannot be considered as personal law [17]. Shiv Sahai Singh in his writing legitimizes the legal authority of the state to interfere in the Muslim Personal law:

The State, therefore, can validly enact measures of social welfare and reform with respect to the matters governed by the Muslim law [18] Professor Werner F. Menski said in his conclusion that the judicial approaches to Indian's constantly contested plural legal realities can only be appreciated through reading the relevant judgments in their original. In the same vein, the uniform civil code debates, as we found, have been more about the politics of governance and nation building, and in that connection about Muslim marginalization, than about deep analysis of meaningful recent legal developments [19].

\section{Legal Uniformity in India: A Political Game}

After the post-colonial dream of India was to achieving social justice through uniform legal provisions in the form of 'one law for all Indians' never turned into a reality. There were several reasons for this. Creating space for personal law system as part of the official law, the Indian Constitution itself recognized in many ways that the people of India were not equal citizens in social reality and that mere declarations about formal equality would be counter- productive. In particular several articles of the Constitution, allowing the state to make special provisions for women, children and other disadvantaged sections of the Indian people (Article 13, 14, 16, and Article 372) [20]. In Shabulameedu v. Subaida 
Beevi, 1970 case Krishna Iyer J heard an appeal by a Muslim husband who had been refusing to pay maintenance to his wife, on the ground that she had been disobedient by leaving him, and so he was not liable to pay her maintenance. Again, it was a fundamental right for Muslims to marry up to four wives as a matter of freedom of religion under Article 25 of the Indian Constitution, had also been rebuked earlier on the ground that the right to marry up to four wives was not a matter of religion [21]. If there is a conflict between a rule of the Muslim personal law and a rule of the general Indian law, the latter would prevail and would override the rule of the personal law. Because it was held that provision 488(3) of the 1898 Code of Criminal Procedure Code applied to all parties irrespective of their personal law. Krishna Iyer $\mathrm{j}$ comments on legal policy [22].

The Indian Constitution directs that the State should endeavor to have a uniform civil code applicable to the entire Indian humanity and, indeed, when motivated by a high public a policy, S. 488 of the Criminal Procedure Code has made such a law, it would be improper for an Indian Court to exclude any section of the community born and bread up on Indian earth from the benefits of that law, importing religious privilege of a somewhat obscurantist order. I have no doubt that it behaves the courts in India to enforce section 488(3) of the Code of Criminal Procedure in favor of Indian women, Hindu, Muslim or other. I will be failing in my duty if I accede to the arguments of the petitioner that Muslim women should be denied the advantages of Para. 2 of the proviso to Section 488(3).

Article 25 of the constitution grants every citizen Right to Religion. The question arises that if every person is having a right to perform his religion in the way they want and it is incorporated as a fundamental right then why any person should go for a common code or legislation. It was intended to curtail and ultimately eliminate the system of personal laws based on religious distinctions. The debate over the Uniform Civil Code is seems to stem from political or academic prejudices and preconceptions. Indian family laws shows convincingly that South Asian indigenous models of legal development, rather than Western blueprints, have been a useful tool in constructing a uniquely modern system of legal regulation.

\section{The Shah Bano Case}

In the Shah Bano case of 1985 whipped up a debate on Muslim personal laws and the need for a UCC. Shah Bano, an elderly Muslim, and mother of five, was divorced by her husband. Her husband refused to pay her maintenance beyond the period of iddat (three-month period after divorce in which she cannot remarry). He argued that according to Muslim personal law he was obliged to pay her maintenance for this period only. The case went up to the Supreme Court which granted her maintenance for life under Section 125 of the Cr.P.C (according to which he had to maintain her until she remarries or dies if she has no means of her own for survival). The Supreme Court held that the Cr.P.C. was common for all and that she could claim maintenance under it. Thus the Muslim personal law cannot be applied here.

Some Muslims perceived this as an attack on their religion and their personal laws and protested loudly against the judgment. This caused the government to pass the Muslim Women (Protection of Rights on Divorce) Act, 1986 which nullified the judgment of the Supreme Court. This act allowed maintenance to a divorced woman only during the period of iddat, according to the provisions of Islamic law. However, in the later judgments, the Supreme Court of India upheld the Shah Bano judgment and the act were nullified.

The court also regretted that the Uniform Civil Code in India had not been given effect to and held that a common civil code will help the cause of national integration by removing loyalties to laws which have contradicting ideologies. In a different case, the court noted 'India is a secular nation and it is a cardinal necessity that religion is distanced from law. Therefore, the task before us is to interpret the law of the land, not in light of the tenets of the parties' religion but in keeping with the legislative intent and prevailing case law'.

The Directive Principles of State Policy are only guiding principles, not enforceable by any court. Yet, as in the above case, the apex court has sometimes, directly or indirectly, expressed itself in favor of a uniform civil code or expressed displeasure at the government's inability to enact it.

\section{Steps towards Uniform Civil Code}

A Uniform Civil Code would help in constructing an Indian national identity and eradicate based on caste and religion. But the proposal was resisted by the drafting committee of the Constitution, on the grounds that it would destroy the cultural identity of minorities. The UCC was placed under the Directive principles, which the state shall endeavor to achieve but which is non-binding. They were also against granting equal property rights to women, fearing the concept of a joint family might crumble because of it. These people saw themselves being singled out as the only religious community whose laws were to be reformed. However, Nehru saw such codification as necessary to unify the Hindu community, which he saw as a first step towards unifying the nation.

The Uniform Civil Code would give women equal rights. Most anti-women ideas among Muslims, does not mean that Muslims have not derived theories of inequality and male 
privilege from the Quran. Particularly, its different treatment of women and men with respect to marriage, polygamy, divorce, evidence, inheritance, etc., and a couple of lines in the text ('men have a degree above women,' and 'men are in charge of the affairs of women [in that] God has preferred them'), are all establishing the Quran's advocacy of sexual inequality and patriarchy.

Another group of people also argue that it would lead to a loss of the culture and the identity of the minorities in the Indian society. These are only some of the significant differences between the different personal laws. Many of them clearly do not treat women at par with men. The proponents of UCC argue that we should have a common law treating women equally as men in all matters involving marriage, divorce, and inheritance. Moreover, it is argued that it will lead to national integration and 'true secularism' and draw minorities into the mainstream and encourage communal harmony.

The Chief Justice of India Y.V. Chandrachud observed that, "A common civil code will help the cause of national integration by removing disparate loyalties to law which have conflicting ideologies". The bench comprising of Chief Justice of India V.N. Khare, Justice S.B. Sinha and Justice A.R. Lakshamanan struck down the Section declaring it to be unconstitutional. Chief Justice Khare stated that, "We would like to State that Article 44 provides that the State shall endeavor to secure for all citizens a uniform civil code throughout the territory of India It is a matter of great regrets that Article 44 of the Constitution has not been given effect to. Parliament is still to step in for framing a common civil code in the country. A common civil code will help the cause of national integration by removing the contradictions based on ideologies."

In Mudgal v. Union of India, the Supreme Court heard a case regarding four Hindu husbands who converted to Islam for the sole purpose of taking additional wives, which is allowed under the Muslim personal laws [23]. The Court held that the second marriage of a Hindu husband after his conversion to Islam is a void marriage and the converted husband is guilty of bigamy, a practice proscribed under Hindu marriage laws. In dicta, the Court recited the Shah Bano dicta in favor of a uniform civil code and added its own reasoning:

Those who preferred to remain in India after the partition fully knew that the Indian leaders did not believe in two-nation or three-nation theory and that in the Indian Republic there was to be only one Nation-Indian nation-and no community could claim to remain a separate entity on the basis of religion [23].
In the most recent Supreme Court case advancing a uniform civil code, the Court examined a section of the Indian Succession Act that affected only the rights of Christians to make charitable or religious bequests [24]. In declaring that section unconstitutional because it violated Article 14, the Court reiterated the sentiment of the previous two cases:

- It is a matter of regret that Art. 44 of the Constitution have not been given effect to.

- Parliament is still to step in for framing a common civil code in the country. A common civil code will help the cause of national integration by removing the contradictions based on ideologies [24].

Shiv Sahai Singh in his writing legitimizes the legal authority of the state to interfere in the Muslim Personal law: The State, therefore, can validly enact measures of social welfare and reform with respect to the matters governed by the Muslim law [18].

On a uniform civil code is not realistic under current circumstances, a number of alternative approaches have been proffered by legal scholars and political theorists. The uniform civil code should serve as a vehicle for the realization of women's equality in India. My suggestion is to enact "Gender Equality laws" and should ensure Civil Rights of the citizens.

Marriage should be legally recognized by a civil marriage registration law through which rights and obligations can be created and ensured.

- The marriage registration should be allowed only after reaching at the legal age of consent.

- Any person female or male may not be allowed to register more than one marriage at the same time. Conditional and forced marriages and marriages against the will of the parties should be illegal and punishable by law.

- The property created during matrimony should be registered in the public register as a common property in the name of both partners.

- The work of both partners through which common property is created, should be considered equal contribution for the creation of the common property. The common registered property should be administered jointly and may not be alienated without the consent of both partners. In case of divorce, the common property should be equally divided. In the case of death of one of the spouses, the inherited property should be divided between the surviving partner and the other inheritors of the deceased in compliance with the applicable law.

- Children of both genders are entitled to an equal share of the inherited property. Inheritors, females and males, can obtain and can renounce his/her share after the registration of their inherited property.

- People of both genders shall have equal access to the 
insurance system and social welfare during their entire life.

\section{References}

1. According to Free dictionary by Farlex Gantoos is an archaic Hindu, Distinguished from a Muslim.

2. A native or inhabitant of an Occidental country.

3. Hastings W, Rama Gopala, Krishnajivana, Viresvara, Krishnacandra, et al. (1776) Vivadarnava setu is a valuable book on Hindu law. Warren Hasting complied this book with the help of ten other scholars to help settle disputes. In 21 sections (taranga). The book was first translated into French and then into English by Nathaniel Brassey Halhed as A Code of Gentoo Law.

4. Ibid.

5. Hasanat W, Koivurova T (2008) Protection of Minorities in Bangladesh (Finland: University of Lapland Press,

6. Ibid.

7. Doniger W (1991) In Sanskrit Manusmrti is informally known as Manu consists of 2685 verses on topics as apparently varied. The Laws of Manu. Newyork: Penguin Books, pp: 16.

8. Doniger W (1991) The Laws of Manu. Newyork: Penguin Books, pp: 116.

9. Doniger W (1991) The Laws of Manu. Newyork: Penguin Books, pp: 115.

10. (2013) The Laws of Manu: Primary Source Lesson. Teaching Women's Rights from Past to Present

11. Manohar Arbat V, Rajaram Sawai K (1987) Cri LJ 977 :
AIR 1987 SC 1100. The responsibility of maintenance of parents by their daughter was again questioned in this case.

12. Dhagamwar V (1989) Towards the Uniform Civil Code, pp: 50-53.

13. Derrett JDM (1978) The Death of Marriage Law, pp: 310.

14. Dhagamwar V (1989) Towards the Uniform Civil Code, pp: 76.

15. Mahmood T (1995) Statutes of Personal Law in Islamic Countries History, Texts and Analysis, 2nd (Edn.). New Delhi: India and Islam Research Council, pp: 54-57.

16. The Nari-o-Shishu Nirjatan Daman Ain, 2000 as amended on 2003 (the suppression off Violence against Women and Children).

17. (1980) The Dowry Prohibition Act.

18. Sahai Singh S (1993) Unification of Divorce Laws in India. New delhi: Deep, pp: 11.

19. Menski WF (2001) Modern Indian Family Law. London: Curzen Press, pp: 408.

20. Menski WF (2001) Modern Indian Family Law. London: Curzen Press, pp: 390.

21. (1957) Badruddin v. Aisha Begum, AllLJ 300.

22. (1970) Shabulameedu v. Subaida Beevi, KLT 4, pp: 9-10.

23. A.I.R. 1995 S.C. 1531, 1533 (India).

24. Vallamattom v. Union of India, A.I.R. 2003 S.C. 2902, 2906. India.

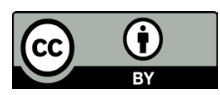

